CENTRE FOR ECOMONIC PERFORMANCE

DISCUSSION PAPER NO. 178

September 1993

HAYEK ON TRADE UNIONS:

SOCIAL PHILOSOPHER OR PROPAGANDIST?

R. RICHARDSON 


\begin{abstract}
Friedrich Hayek wrote frequently on the consequences of trade unions, usually highly critically, making large claims about their very adverse economic and social impact. A close analysis of his work demonstrates that his judgments do not rest on a theory of trade unions which is clearly different from a conventional treatment; nor does he anywhere present any relevant new empirical work. Further, his methodological writings seem to disbar him from making the kind of empirical claims on trade unions that feature throughout his writings. The conclusion is that he was morally so offended by the extraordinary legal immunities which the trade unions had acquired that his judgment deserted him, so that he descended into a series of wholly untenable empirical assertions. His significant influence on thinking and policy on industrial relations matters, at least in the UK, looks to have been based far more on powerful emotions than on science.
\end{abstract}

This paper was produced as part of the Centre's Programme on Industrial Relations Programme 
HAYEK ON TRADE UNIONS:

SOCIAL PHILOSPHER OR PROPAGANDIST?

\author{
Ray Richardson
}

Page

Introduction 1

Hayek's theory of trade unions 5

$\begin{array}{ll}\text { Do Hayek's assertions agree with the facts? } & 16\end{array}$

$\begin{array}{ll}\text { Hayek and testing } & 19\end{array}$

$\begin{array}{ll}\text { Conclusions } & 21\end{array}$

Endnotes $\quad 23$

References $\quad 24$ 


\title{
HAYEK ON TRADE UNIONS: SOCIAL PHILOSOPHER OR PROPAGANDIST?
}

\author{
Ray Richardson ${ }^{1}$
}

\section{Introduction}

When reviewing one of Friedrich Hayek's books (Hayek, 1991) ${ }^{2}$ recently I became conscious of his willingness to make a number of important empirical judgments, particularly on trade unions, without accompanying them by any supporting evidence. As an example, just one among many, consider his remarkable claim (in 1980s Unemployment and the Unions, ${ }_{\text {, }}$ ) that the legalised powers acquired by British trade unions prior to 1980 became,

"the biggest obstacle to raising the living standards of the working class as a whole...the chief cause of the unnecessarily big differences between the best- and worst-paid workers...the prime source of unemployment...[and]...the main reason for the decline of the British economy in general" (Hayek, 1991, p.344).

That is quite a charge sheet, one worth analysing more slowly. Hayek does not content himself with the claim that, because of their legalised powers, British unions were an obstacle to raising living standards among the working class, nor even that they were an important obstacle; he makes the far more exacting empirical assertion that, among all the many possible candidates, trade unions were the biggest obstacle. Unions were not merely one cause of 'unnecessary' wage differentials, nor even a major cause; they were the chief cause. 
Similarly, unions were the prime source of unemployment and the main reason for the decline of the British economy.

Elsewhere, he makes even stronger claims. In the same publication, for example, he asserts that

"the policies of the unions [are], under normal conditions, the sole cause of extensive lasting unemployment" (my underlining, Hayek, 1991, p.318).

Now, 'normal conditions' and 'extensive and lasting' have to be defined, but here he has managed not only to rank the possible causes of 'extensive lasting' unemployment under 'normal' conditions, but also to eliminate all but one of them from his enquiries.

Nor were unions seen to be blameless in the generation of inflation. Hayek writes that

"[ $t$ ]he problem of inflation, the problem of employment, and the problem of excessive power of the trade unions have become inseparable in present-day Britain" (Hayek, 1991, p.319).

I can find no ranking from him on the causes of inflation but there is no doubt that Hayek would have had unions well represented in the dock.

I want to consider how should we react to these claims? Prima facie they look extreme. We could therefore see them as unguarded or rash judgments, made by someone who was past the peak of his formidable intellectual powers. We could alternatively see them as hyperbole, as the rhetorical excess of someone who wished to play politics, as propaganda. The second of these interpretations runs counter to what little I know about the man. Arthur Seldon, someone who studied under and worked with Hayek for many years, has said 'I remember that Hayek never showed political bias'; Shirley Letwin recalls him saying 'The best economists were those who 
had no influence on practical affairs, because they were not distracted by thinking about what is "politically possible"'. ${ }^{3}$ Taking my lead from observations like these, therefore, I prefer not to interpret Hayek's claims as polemical but to start by taking them at face value, paying Hayek the courtesy of believing that he knew exactly what he was saying, that he had reflected deeply on the issues, and that his very strong empirical propositions were the fruits of careful, dispassionate analysis. A second, and equally powerful, reason for taking them seriously is that their origins are clearly visible in The Constitution of Liberty, an unambiguously scholarly work of great weight and considerable importance. A final reason for taking them seriously is that, whether he sought it or not, Hayek was not without influence on public policy, certainly in the UK; his views manifestly gave encouragement to successive UK Governments after 1979, and helped to provide an intellectual basis for their energetic reforms of industrial relations legislation.

My basic question will be, how did Hayek know these things? How did he know that, alongside all the other possible inhibitions on raising the living standards of the working class as a whole, it was the influence of trade unions that was the most baleful? How did he know that unions were 'normally' the sole cause of extensive lasting unemployment, and that nothing else made a contribution? How did he know that it was the legal powers granted to unions and not, for example, the inadequacies of British management, or the grotesque failures of our educational system, or the inevitable penalties of being the first economy to experience industrialisation, or an acquired distaste amongst certain social groups for being 'in trade', or a series of profoundly misconceived economic policies of successive governments that was the main reason for British economic decline? 
When addressing this kind of question one would usually start by analysing of the logic of the relevant theory and then go on to consider the evidence that had been marshalled. That procedure is hardly possible here. First, Hayek does not lay out his theory of trade unions in a conventional, tight fashion, so that one cannot know precisely why unions might be thought to have the kind of consequences claimed. Second, Hayek rarely cites supporting evidence. Quite often, his judgments appear almost out of the blue. My alternative approach, therefore, is first to compare Hayek with Friedman, in order to see whether anything extra can be discerned in Hayek's theoretical approach that might support his very strong conclusions. I will conclude that it is hard to identify any such extra element, so that Hayek's view must rest on a different interpretation of the evidence. I will then consider whether his propositions had any support from the facts as they appeared at the time (and later). Finally, I will ask whether his willingness to make such astonishingly unqualified and precise empirical judgments sits well with his more general methodological position on the merits of empirical, particularly statistical, enquiry. 


\section{HAYEK'S THEORY OF TRADE UNIONS}

As a context within which to judge Hayek's theoretical position I will start with that of Milton Friedman, another economist who might be expected to take a generally critical view of the virtues of trade unions. Friedman, of course, also taught at the University of Chicago, and his analysis was certainly known to Hayek.

Writing in the early 1960s, just after The Constitution of Liberty Friedman observed, of unions in the USA, that

"[t]here is a similar tendency to overestimate the importance of monopoly on the side of labor. Labor unions include roughly a quarter of the working population and this greatly overestimates the importance of unions on the structure of wages. Many unions are utterly ineffective. Even the strong and powerful unions have only a limited effect on the wage structure .... This is not to say that unions are unimportant . . . .I once made a rough estimate that because of unions something like 10 to 15 per cent of the working population has had its wage rates raised by something like 10 to 15 per cent. This means that something like 85 or 90 per cent of the working population has had its wage rates reduced by some 4 per cent .... If unions raise wage rates in a particular occupation ... they necessarily make the amount of employment available in that occupation ... less than it would otherwise be .... The effect is an increased number of persons seeking other jobs, which forces down wages in other occupations ... . Unions have therefore not only harmed the public at large and workers as whole by distorting the use of labor; they have also made the incomes of the working class more unequal by reducing the opportunities available to the most disadvantaged workers" (Friedman, 1962, p123-4).

Friedman's analysis of unions was given at greater length in an earlier publication (Wright, 1953) but the above quotation presents his view more succinctly. It clearly differs from Hayek's. Unions certainly have an effect on the wage structure, but the effect looks to be relatively small; unions do not obviously cause lasting unemployment, because the workers who are displaced from the unionised sectors can find alternative employment (albeit not as well-paid) in the unorganised sectors; 
as unions tend to be more powerful among the relatively skilled manual trades, they also tend to widen the distribution of earnings. There is no suggestion that unions have lasting effects on the rate of economic growth, although they are clearly seen to reduce the level of aggregate income below what it would otherwise be. The activities of unions are to be regretted, but their importance is easy to overstate.

Friedman's analysis is squarely within the Marshallian tradition and is backed by some limited, but acutely observed, statistical analysis. Another economist writing on some of these issues in Chicago in the 1950s and early 1960s was H.G. Lewis. In a monumentally scholarly work on the impact of unions on relative wages in the USA, Lewis concluded that Friedman's empirical judgments on relative wages were about right (Lewis, 1963). These, of course, are American views, and unionisation in the US was not as extensive as in many European countries with which Hayek was familiar. Even so, Hayek rarely draws careful empirical distinctions between the two geographical areas, not at least in The Constitution of Liberty. His analysis is quite general and tends to indict unions in all developed countries in a roughly similar fashion.

His starting point is important. Hayek does not approach these issues with the light-handed rational touch of a Marshallian economist. He begins instead with the observation that trade unions are the glaring exception to the rule of law in modern societies; they

"have become the only important instance in which governments signally fail in their prime function -- the prevention of coercion and violence" (Hayek, 1960, p.267).

The root of their power was an ability to coerce, an ability which was protected by the law -- Hayek specified their main coercive weapons to be 
intimidatory picketing, the closed shop and secondary action:

"[t]he present coercive powers of unions thus rest chiefly on the use of methods which would not be tolerated for any other purpose... In the first place, the unions rely...on the use of the picket line as an instrument of intimidation...next to the toleration of picketing, the chief factor which enables unions to coerce individual workers is the sanction by both legislation and jurisdiction of the closed...shop... We must also regard as inadmissable methods of coercion all secondary strikes and boycotts which are used not as an instrument of wage bargaining but solely as a means of forcing other workers to fall in with union policies." (Hayek, 1960, p.275).

In certain circumstances, Hayek asserts, these powers could have dramatic effects; 'any union effectively controlling all potential workers of a firm or industry can exercise almost unlimited pressure on the employer and ... particularly where a great amount of capital has been invested in specialized equipment, such a union can practically expropriate the owner and command nearly the whole return of his enterprise' (Hayek, 1960, p.270). Only after this dark opening do we move on to more commonplace events, although the texture of the language retains an element of violent assertion throughout.

Unions were seen to interfere with free market allocations by changing relative wages (and hence relative costs and relative prices);

"unions in particular industries or crafts may well raise the wages of their members by forcing others to stay in less-well-paid occupations. How great a distortion of the wage structure this in fact causes is difficult to say... [but]...there can be little doubt that this distortion is considerable. It is important to note that such policies can be employed successfully only in relatively prosperous and highly paid occupations and that they will therefore result in the exploitation of the relatively poor by the better-off." (Hayek, 1960, p.271).

Hayek provides no supporting evidence to show that the distortion was 'considerable', nor is 'considerable' defined -- what we are given instead is an assertion. His claim that unions can be successful only in the relatively prosperous 
trades is also a strong one, and it will surprise many of those who have studied, for example, the impact of British unions which organise amongst less skilled workers.

This passage is followed immediately by another assertion; 'there can be little doubt that, so far as relative wages in major industries and trades are concerned, unions today are largely responsible for an inequality which has no function and is entirely the result of privilege'. If this is no more than a re-statement of the point that unions have succeeded in distorting relative wages it is unexceptional. But the language suggests more. It implies that unions are by far the chief cause of any departure from the wage differentials that would be observed in a completely free market. For us to be confident that Hayek is correct we surely need to be given some idea of what the free market differentials would be, but Hayek does not explicitly address this issue (indeed, he elsewhere claims these to be unknowable). What he does instead is to leap from the empirically verifiable point of positive union mark-ups to a conjecture, masquerading as an obvious fact, about the causes of wage dispersion. If this were an isolated instance it might be excused as careless writing; in fact, it is an integral part of Hayek's usual style on these issues. One might fairly say that he is a conviction economist.

In The Constitution of Liberty Hayek is concerned to stress that unions cannot raise the average real wage: 'there can now be no doubt that they [unions] cannot in the long run increase real wages for all wishing to work above the level that would establish itself in a free market... Their success in raising real wages ... can benefit only a particular group at the expense of others. It will therefore serve only a sectional interest' (Hayek, 1960, p.270). And again, '[t]his means that their activities necessarily reduce the productivity of labour all round and therefore also the general 
level of real wages' (Hayek, 1960, p.271).

What about the impact of unions on unemployment? It is true that Hayek does hint that unions will cause unemployment by displacing workers from the unionised sector. But it is hard to see that displacement is sufficient, because, under conventional arguments, wages elsewhere would adjust downwards sufficiently to absorb the workers displaced from the unionised trades. Things would be radically different (i) if governments were to intervene to stop the unskilled market from clearing, or (ii) if the unions were as strong in this market as elsewhere. Hayek explicitly discounts the second and does not mention the first in his chapter on unions. In a subsequent chapter, however, he does discuss the role of unemployment compensation, where he writes

"t]he chief significance of the comprehensive systems of unemployment compensation that have been adopted in all Western countries... is that they operate in a labor market dominated by the coercive action of unions and that they have been designed under strong union influence with the aim of assisting the unions in their wage policies. A system in which a worker is regarded as unable to find employment and therefore is entitled to benefit because the workers in the firm or industry in which he seeks employment are on strike necessarily becomes a major support of union wage pressure." (Hayek, 1960, p.302).

Hayek's use of language may now be familiar. Western labor markets are said to be 'dominated' by the coercive actions of unions, but 'dominated' (an extremely strong word) is not defined, and the fact of domination (if it be a fact) is never documented. In other contexts this would, justly, be regarded not as scholarly analysis but as the biased language of prejudice. A second example of this quality comes with the claim that those who designed these systems did so to support union wage policies. There is a strong implication that they did so consciously, and that this 
was their sole aim. It is demonstrably the case that neither of these propositions is generally correct. This is not to deny that unions were assisted by unemployment compensation schemes, nor that the schemes are almost certain to have contributed to higher unemployment. But Hayek is not satisfied by such qualitative statements. Going beyond them, however, requires a lot more than obiter dicta.

One strange omission from Hayek's charge sheet against unions in The Constitution of Liberty is his silence on the matter of minimum wages, because these would normally be thought to prevent market clearing at the bottom of the occupational and skill distribution. He could well have pointed out that unions are among the most forceful advocates of minimum wages, that minimum wages can be seen as a device to limit the extent to which union members are priced out of work, and that, by preventing the unorganised labour markets from clearing, they may make an important contribution to unemployment.

One issue on which Hayek clearly differs from Friedman is on inflation. Hayek believed that unions' monopoly-based increases in money wages led to inflation, whereas Friedman was sceptical. But Hayek emphasised that his own position was predicated on governments having made a commitment to full employment, so that they had to print money to offset the unemployment effects of higher money wages:

"[i]f labour insists on a level of money wages too high to allow of full employment, the supply of money must be so increased as to raise prices to a level where the real value of the prevailing money wages is no longer greater than the productivity of the workers seeking employment. In practice, this necesarily means that each separate union, in its attempt to overtake the value of money, will never cease to insist on further increases in money wages and that the aggregate effort of the unions will thus bring about progressive inflation," (Hayek, 1960, p.280).

The problem with this position is that Hayek virtually assumes his result in the first sentence of the quotation. It is not clear from what he says how unions 
succeed in pushing up, or continuing to push up, average money wages above the level to which they would be taken by all the other influences. It is easy to agree that they change the wage structure, and even that they reduce average real wages. But Hayek provides no justification to support the idea that they raise money wages on average; for him they just insist and succeed. The effect is merely assumed. If it is assumed, and if governments do seek to offset any resulting unemployment, then the unions' partial culpability in the inflationary process is established. But Hayek still has to explain why, ceteris paribus, the rise in wages of the unionised will not be balanced by a fall in wages of the non-unionised.

The issue of inflation apart, Hayek of The Constitution of Liberty is not analytically so different from Friedman. The intangibles differ, the overtones are darker, and the language is more menacing, but the core theory is from the same stable. Hayek forbears from statistical analysis, whereas Friedman is prepared to make some rough calculations to support his position. But the real difference is in the language and in Hayek's willingness, even in The Constitution of Liberty, to go beyond what is demonstrated, and to make unnecessarily tendentious and careless empirical statements. Thus, he can write

"[m]ost people probably still believe that a "labor dispute" normally means a disagreement about remuneration and the conditions of employment, while as often as not its sole cause is an attempt on the part of the unions to force unwilling workers to join" (Hayek, 1960, p.268).

This assertion was not limited by time or place, but it would certainly not apply to Britain in the 1950s (or for nearly all the period since that time), when, overwhelmingly, strikes were about money.

A striking feature of the economic analysis in The Constitution of Liberty is 
that it is fundamentally static (more specifically, the analysis is comparative static), which is perhaps why Hayek's conclusions are so similar to those of the Marshallian Friedman. Unions appear, take their monopoly profit, have an impact on capital/labour ratios, affect productivity levels and so on. But it is hard to see the dynamics. It is hard, in other words, to see why unions should continue to have an additional effect on, say, the subsequent rate of growth or on economic decline. One senses in the writing, however, that a different tradition, a cloudier Continental one which sees economic events as a more organic and protean process, is trying to escape. In the later writings this other tradition is somewhat more visible.

In Full Employment at Any Price, for example, Hayek writes the following; "[t]he true, but untestable, explanation of extensive unemployment ascribes it to a discrepancy between the distribution of labour ... between industries ... and the distribution of demand between their products' (Hayek, 1991, p.271).

Anything that increases that discrepancy presumably reduces employment and increases unemployment. We leave to one side the implications of this hypothesis being untestable (and the claim that, somehow, we anyway know it to be true), so as to see what it might say about the effects of trade unions. In particular, how in a dynamic system do unions cause discrepancies that differ from those in a world of comparative statics? Given that elsewhere they are said normally to be the sole cause of extensive lasting unemployment, they must be the sole cause of an important set of additional discrepancies.

Hayek is surely correct to argue that a dynamic economy is characterised by a continuing change in the structure of demands, which generally implies the desirability of changing the structure of employment. This latter change requires signals, which in turn, for Hayek, implies changes in relative wages. The problem 
with unions, it would seem, is that they are seen to throttle changes in relative wages. But what presumption is there that unions do affect either the size or the timing of changes in relative wages in the face of all sorts of shocks in the economic system?

Assume demand picks up in a strongly unionised sector. Standard theory, based on the maximisation of some stable objective function, would predict that this would result in some rise in relative wages for the unionised workers. The extent of the rise would depend on a number of factors, including the objectives and beliefs of the trade unions. But it is not clear that the change in the relative wage would be much different in the unionised situation from that in a free market; we might expect the level of the relative wage to be greater with unions than in a free market both before and after the exogenous shock, but we would be less confident that the size of the change itself would be different. It is not yet obvious, therefore, that unions lead to additional 'discrepancies' in a dynamic as compared with a comparative static world.

It is possible that unions slow down the adjustment in wages, especially where they are party to relatively long term contracts, as in the US. Even in this case their contribution to resource allocation in the face of exogenous shocks is not clear cut. If demand rises in a unionised sector where wages are sticky, the gap between the free market and the union wage shrinks, because the increase in demand would raise the former. Any existing misallocation of resources is presumably reduced, because relative wages are now closer to the efficient, free market level. This should, on Hayek's argument, reduce unemployment. If, to the contrary, demand were to fall in a unionised sector characterised by sticky wages, we would get the reverse. On average, therefore, the effect on unemployment of any additional discrepancy from 
the analysis of the dynamics might well net out to zero; it is certainly not pre-ordained to be positive. To be persuaded, we need to have the dynamics, and perhaps the source of shocks, modelled in some detail, but Hayek does not do this.4 It is therefore far from clear that unions have a special role to play, still less a dominant role, in Hayek's preferred theory of unemployment.

The Hayek of 1980s Unemployment and the Unions had come to the view that trade unions were the principal source of most of Britain's important economic problems (see the opening quotation above). Their main, legally based coercive powers were now seen to be 'intimidatory picketing, preventing non-members from doing particular kinds of jobs such as 'demarcation' rules, and the closed shop' (Hayek, 1991, p.345-6). The second of these looks like a category error. One might agree that restrictive practices were extremely costly, but it is better to see them (like union wage mark-ups) as a consequence of power rather than being a legally recognised right. Hayek now suspects that the powers of unions are not in the interest even of union members;

"[i]t is more than doubtful, however, whether in the long run these selfish practices have improved the real wages of even those workers whose unions have been most successful in driving up their relative wages... Such practices ... have turned Britain, which at one time had the highest wages in Europe, into a relatively low-wage economy" (Hayek, 1991, p.346).

It will be noted that they are not said to be among the factors which turned Britain into a relatively low wage economy -- for Hayek, they seem to have been sufficient by themselves.

I have said enough to suggest that, from the more orthodox Chicagoan context offered by Friedman, the additional theoretical points raised by Hayek do not unambiguously support the case that unions are as influential as he claimed. We 
must therefore move on to empirical issues. 


\section{DO HAYEK'S ASSERTIONS AGREE WITH THE FACTS?}

It would not be enough for a defender of Hayek's position to establish that unions had made a contribution, even an important one, to the outcomes I have been discussing. He would also have to demonstrate that their role was as powerful and dominating as that claimed by Hayek. How might this be done? One problem is that Hayek at no point discusses the evidence in an orderly way. On the issue of long term economic decline, he does not even sketch a framework which would allow one to identify the set of possible causes. We are therefore left with a set of virtually ex cathedra statements.

In order to judge, for example, whether unions were indeed the sole cause of extensive lasting unemployment one might relate unemployment rates across countries to different legal systems or the level of trade union membership, arguing that where unions do not have the legally guaranteed rights which Hayek regards as so dangerous a country will not have extensive and lasting unemployment. If this were done, say, at present across western Europe it is not easy to see much of a pattern -- it is certainly easy to cite countries, France is one, where union membership is extremely low but unemployment has been in a clear sense high for some considerable time.

An alternative approach would be to concentrate on a single country and chart movements in unemployment against changes in that country's legal system or trade union membership levels. Well, unemployment in the UK is currently (1993) near to record levels but most of the trade union powers to which Hayek raised objections have been removed, and union membership is nearly one third below what it was ten to fifteen years ago. Neither of these are completely convincing tests but they do 
suggest that it would be hard to establish unions' sole responsibility for extensive lasting unemployment .

Hayek stressed the importance of the coercive power of intimidatory picketing and secondary action. But these were used in conjunction with strikes, and Britain has never obviously had, by international standards, a grave strike problem. The amount of time the average British worker spends on strike rarely exceeds a few hours per year. On most calculations Britain is normally somewhere in the middle of the international league table on strike incidence. Strikes were, of course, a very serious problem for selected firms in selected industries, but this means that they (together with the genuine prospect of intimidatory picketing) must have been pretty distant for the typical firm. It is difficult to believe that so rarely used a weapon could have had the dramatic and pervasive effects that Hayek saw.

Perhaps Hayek felt that picketing was so potent a weapon that it rarely had to be used -- its importance was inversely related to its use. This would be reminiscent of another of his arguments, concerning the set of coercive powers that he saw unions as having:-

"The case against these [powers] is strengthened rather than weakened by the fact that unions have often shown much restraint in exercising them. It is precisely because, in the existing legal situation, unions could do infinitely more harm than they do, and because we owe it to the moderation and good sense of many union leaders, that the situation is not much worse that we cannot afford to allow the present state of affairs to continue." (Hayek, 1960, p.269).

This looks a pretty disingenuous argument; one can hardly imagine him arguing that, were unions to use all their powers to the full, the case against them would be weakened. If unions were indeed not using their powers to the full, Hayek 
should surely have been a little less, rather than more, concerned.

The position on closed shops is similar to that on intimidatory picketing. Formal closed shops in the UK never encompassed more than a minority of unionised workers, while union membership barely attained majority status in the labour force (and then only briefly). Econometric work finds that appreciable union wage mark-ups are often hard to detect outside the closed shop sectors, and that even there it was only in a subset of closed shops that the mark-up reached double figures. Could the closed shop, itself an institution that grew fast only in the late-1960s and 1970s, really have been the principal cause of Britain's economic decline, or the reason why we now enjoy eleven per cent unemployment? The last point is, of course, slightly malicious. Britain no longer has formal, legally tolerated closed shops, intimidatory picketing or secondary action, but we do have extensive, lasting unemployment. It is overwhelmingly probable that all these issues are a great deal more complicated than Hayek's view permitted him to appreciate. 


\section{HAYEK AND TESTING}

Hayek would, I presume, discount any enquiry of the kind just sketched. His

Nobel Prize lecture (later published under the title of The Pretence of Knowledge, Hayek, 1991, pp.280-291) was one of his attempts to demonstrate how our ability to understand economic phenomena empirically was inherently extremely limited. He writes,

"in the study of such "essentially complex" phenomena ${ }^{5}$ as the market, which depend on the actions of many individuals, all the circumstances that will determine the outcome of a process...will hardly ever be fully known or measurable" (Hayek, 1991, p.282, italics in the original).

He illustrates his position by considering the causes of unemployment:

"The correct explanation appears to me to be the existence of discrepancies between the distribution of demand among the different goods and services and the allocation of labour and other resources among the production of those outputs. We possess a fairly good "qualitative" knowledge of the forces by which a correspondence between demand and supply in the different sectors of the economic system is brought about, of the conditions under which it will be achieved, and of the factors likely to prevent such an adjustment. The separate steps in the account of this process rely on facts of everyday experience... We know, in other words, the general conditions in which what we call, somewhat misleadingly, an "equilibrium" will establish itself; but we will never know the particular prices or wages that would exist if the market were to bring about such an equilibrium." (ibid).

A theory then is supported by 'the facts of everyday experience'. These somehow give us our 'qualitative knowledge' of 'essentially complex' phenomena; what this does is to permit the observer to make 'pattern predictions', which Hayek defines as

"predictions of some of the general attributes of the structures that will form themselves, but not containing specific statements about the individual elements of which the structures will be made up" (Hayek, 1991, p.284). 
I think it is fair to conclude from this that Hayek must argue that 'the facts of everyday experience' inform us that trade unions have had a powerful and socially unfortunate impact; but even if we grant him this knowledge, he surely must also argue, given that we can never know the relevant 'particular' facts, that we will not be able to make specific statements about individual elements. Does this not inevitably imply that we can never gauge how far, in absolute terms, any one of these elements (trade unions for example) have taken us from the free market equilibria with respect to unemployment, the distribution of earnings, inflation or economic growth?

For him therefore, it must in principle be impossible to know the individual contribution of any of the potential specific causes of an 'essentially complex' outcome. But if he cannot know that, neither can he rank the different causes, nor confidently give prime responsibility to any one of them. Hayek's own methodological precepts, therefore, should prevented him from making the empirical judgments which have been our focus. 


\section{CONCLUSIONS}

There would have been nothing especially controversial if Hayek had merely wished to say that British trade unions had almost certainly been an important source of economic inefficiency (even though that is far from being the whole of their legacy). But he wanted to go much fur1ther. In analysing a set of immensely complex social forces he was sufficiently confident implicitly to rank the possible causes, and to say that one rather than another was the most powerful. Any such empirical claim deserves to be taken seriously only if it is the result of a thorough examination of the evidence which isolates the contribution of one of the possible causes (trade unions) from that of all the others. It cannot be enough to rely on a theory, no matter how plausible or convincing that might seem to be. But Hayek's theoretical arguments on these issues are not especially novel, and he produces no empirical results of his own, preferring instead to quote the fragmentary work of other writers, themselves a highly selected subset from all those who had addressed the relevant issues. One may illustrate the frailty of his position by asking the following question:- if unions were the biggest obstacle to raising living standards, then what was the next greatest obstacle? How, in logic, could Hayek possibly know the one without the other?

In many ways this has been a difficult series of arguments for me to make, because I am broadly sympathetic to much of Hayek's underlying position. I certainly would not wish to be interpreted as arguing that unions have been unimportant, still less benign, in their complex economic legacy (although their non-economic legacy is, perhaps, another matter). With Friedman, I am confident that, at least in the UK, they have been an enemy of economic efficiency. Nor would I wish to deny some of Hayek's strictures on econometrics (for example the damaging reliance on what 
seems to be measurable, or the very free use economists make of 'proxies' or dummy variables). But Hayek's methodological position is surely too restrictive, and we can reasonably claim to know more than he allows. What we do know, I suggest, is that his empirical judgments on trade unions are vastly overblown. Certainly his own methodological position means that he himself has no basis on which to make them. My own suspicion is that he was morally so offended by the extraordinary legal immunities which the trade unions had acquired that his judgment deserted him, so that he descended into a series of wholly untenable empirical assertions. I would not like to charge him with being a propagandist, but on the issues discussed in this paper he certainly seems to have been in the grip of powerful emotions. 


\section{ENDNOTES}

1. Department of Industrial Relations and Centre for Economic Performance, London School of Economics. I would like to thank my colleagues Stephen Dunn, Bob Gould, and John Kelly for comments on an earlier draft, which was given at the Hayek Memorial Conference in London in April 1993. The Centre for Economic Performance is financed by the Economic and Social Research Council.

2. This was a collection of pieces he had done for the IEA over the years.

3. Both of these statements come from tributes paid to Hayek at a memorial meeting at the London School of Economics in September 1992.

4. I am abstracting throughout from search theories of unemployment; this might be unfair to Hayek because, although he was (as far as I know) never explicit about search behaviour, it should be possible to fit it in to his view of economic events.

5. i.e. something which 'must refer to a large number of particular facts, all of which must be ascertained before we can derive a prediction from it, or test it' (Hayek, 1991, p.289, italics in the original). 


\section{REFERENCES}

M. Friedman, (1962), Capitalism and Freedom, (Chicago: University Press).

F.A. Hayek, (1960), The Constitution of Liberty, (London: Routledge and Kegan Paul).

F.A. Hayek, (1991), Economic Freedom, (Oxford: Basil Blackwell).

H.G. Lewis, (1963), Unionism and Relative Wages in the United States, (Chicago:

University Press).

D.M. Wright, (ed.), (1951), The Impact of the Union, (New York: Harcourt, Brace). 